\title{
Preserving Minangkabau Traditional Building In West Sumatera, Indonesia: Toward Sustainable Community
}

\author{
Noviarti \\ Department of Civil Engineering, Sekolah Tinggi Teknologi Payakumbuh. \\ Campus STT Payakumbuh. 26227. West Sumatera, Indonesia \\ Ranti Irsa \\ Department of Computer Engineering, Sekolah Tinggi Teknologi Payakumbuh. \\ Campus STT Payakumbuh. 26227. West Sumatera, Indonesia. \\ Andi Putra \\ Department of Computer Engineering, Sekolah Tinggi Teknologi Payakumbuh. \\ Campus STT Payakumbuh. 26227. West Sumatera, Indonesia.

\section{Astuti Masdar} \\ Department of Civil Engineering, Sekolah Tinggi Teknologi Payakumbuh. \\ Campus STT Payakumbuh. 26227. West Sumatera, Indonesia
}

\section{Doi:10.5901/mjss.2013.v4n10p465}

\section{Abstract}

\begin{abstract}
Minangkabau traditional house is part of Indonesia's rich cultural asset with its historical and normative values. Beside custom homes, Minangkabau traditional building also serves as a place to stay in the context of human habitat but has slowly endangered its sustainability. The purpose of this study was to analyze the current physic conditions of this type of building by area. The study also aims to analyze the community participation in preserving this building in West Sumatra Indonesia. This is a quantitative study. Primary data was collected through a questionnaire survey. The total of this type of building amounts to 1,122. The study found that nearly $19.37 \%$ of traditional buildings are not occupied because of damages. In addition, there are influences of urbanization impact in urban community on the sustainability of the buildings. This research, suggested that the government should emphasize both maintenance and protection of traditional buildings by establishing policies in view of sustainable development planning.
\end{abstract}

Keywords: Preservation, cultural heritage, sustainable community, human habitat, Minangkabau traditional building

\section{Introduction}

Modern life is growing very fast, and lifestyle changes that require compliance in accordance with the new requirements, have spurred many extinctions, damages and destruction of cultural heritage. Naturally, the cultural heritage in a dynamic environment will inevitably experience growth and change along with the changing times. Heritage is a component that has a relationship with a valued past and a source for the present and future (Ministry of Environment Indonesia 2008). Preserving the Minangkabau traditional building as a social identity is not only the responsibility of society but needs to be supported by the government. Information regarding the characteristics of the Minangkabau traditional building is very much in need of assessment and conservation measures so that the social and cultural identity in the Minangkabau can be preserved by present and future generations.

The Minangkabau traditional building is one of the social identity characteristics that is essential for the Minangkabau ethnics in West Sumatra. Furthermore, it also became part of the regional identity in terms of "material heritage" for the Minangkabau ethnics. Although the current situation and the existence of Minangkabau traditional building in some areas in West Sumatra is worrisome, sometimes these traditional houses are uninhabited because the owners do not live in them. In addition the physical condition of many Minangkabau traditional building is very poorly 
maintained and damaged. Besides the economic factor, owners need to pay high prices to repair or renovate them. The difficulty in getting wood is also a constraint faced by the community to repair the damaged houses. Some of the factors categorized as internal and external are a constraint in the preservation of traditional Minangkabau house (Noviarti, Jamilus and Nelmawarni 2009; Ranti Irsa et al 2012; Noviarti et al 2013).

Previous research about Minangkabau traditional building paid more attention to the architectural aspects. Elfida Agus (2006) studied the topology, morphology and typology of Minangkabau traditional building. The cultural values, patterns and shapes have also been studied (Sudirman Is 2006; 2007). In addition to the traditional home space transformation were also researched (Al Busyra Fuadi 2006). Minangkabau traditional building is one form of manifestation of Minangkabau culture (Al Busyra Fuadi 2006). In the Minangkabau society, the Minangkabau traditional building as architecture is really a reflection of social and cultural expression of society, and displays specific form of harmony with its environment. There is harmony between natural and built environments (Elfida Agus, 2006; Sudirman Is 2007).

Traditional building is a Minangkabau architecture that reveals the shape and the space environment according to the rules in society. Traditional houses are also a source of inspiration to be used as a basis for planning the form of modern architecture (Elfida Agus 2006, Sudirman Is 2006; 2007). Even the house for the community is a sign of cultural heritage that retain the typical architecture of Minangkabau ethnics (Elfida Agus 2006). Along with the times, the traditional home changed. Among the changes were those in function, form, construction, structure and spatial structure. These changes can be caused by the influence that comes from society itself and are caused by acculturation (Sudirman Is 2007).

\section{Human habitat and Minangkabau traditional building}

As a residence, Minangkabau traditional building is part of man-made habitats that evolved over time. The extent of development of human habitat of traditional Minangkabau houses can be related to the concept of preservation. Preservation of the cultural heritage of a city is an area management that have historical and cultural values in order to accept changes leading to sustainable development. Preservation means fixed, immutable, and eternal. According to Carmona (2003), preservation relate with sustainability. Preservation of historic building or of cultural value as development, is one indicator of the sustainable development which meets the needs of present and future generations whilst there is a balance of economic and social development and environment. The concept of conservation has an aim to keep the identity of an environment (Ministry of Environment Indonesia 2008). In other words the preservation emphasize on the continuity of change in order that environmental identity is still maintained (Adhisakti 1992).

Based on the function role, the traditional Minangkabau houses function as a dwelling or as a custom home for family (ethnic) activities. As a residence, this house is occupied only by family members (women only) to do daily activities, while when it functions as a custom home it is the place to implement the consensus and traditional ceremonies. Traditionally, the main function of traditional Minangkabau houses is a symbol to keep and maintain a system of matrilineal culture. Through these traditional houses, people maintain the system of matrilineal Minangkabau (Al Busyra Fuadi 2006; Navis 1984; Sudirman Is 2006; 2007). In addition, the existence of a traditional house is also a place to teach the values of traditional Minangkabau.

Based on the historical aspect, the existence of the house is even associated with a history origin of the ancestors of the Minangkabau. Based on the historical origins, the arrival of the ancestors of the Minangkabau, Minangkabau area consists of 3 main areas (Darek), commonly referred to as LUHAK (Dobbin 1983, Graves 1981). The other areas are known as LUHAK Tanah Datar, Agam and LUHAK lima puluh Kota. A different type of Minangkabau traditional bulding can be found based on these three areas. According to Bustami (1979) there are different forms and types of Minangkabau traditional building based on the alignment or custom patterns of luhak. Although there are different types and forms of Minangkabau traditional house, in general the difference is determined by the number of pillars, flooring, or end of the building while the other features are the same (Sudirman Is 2007).

\section{Research methodology}

\subsection{Area of Study}

The majority of Minangkabau people inhabit the area of West Sumatera province on Sumatera Island. This study was conducted on traditional Minangkabau building of the West Sumatera Province, a province of Indonesia (Fig.1). West 
Sumatera consists of 19 cities/regencies. This study involves only two areas in West Sumatera namely Payakumbuh (80.34 km2) representing the urban area, and Limapuluh Kota $(3,354.30 \mathrm{~km} 2)$ representing the rural area. Payakumbuh topography varies between plain and hilly spaces with an elevation of $514 \mathrm{~m}$ sea surface. The total number of households in this city is 25,302 with an average density population of 1,454 people per square kilometre. Demographically, according to 2010 Census, total population of Payakumbuh city is over 116,910 people whereas the population of Limapuluh Kota Regency is 348,249 . Its topography varies such as flat, bumpy, and hilly with elevation of sea between 110 meters and 2,261 metres. The total number of households in this regency is 87,160 with an average density population of 100 people per square kilometre.

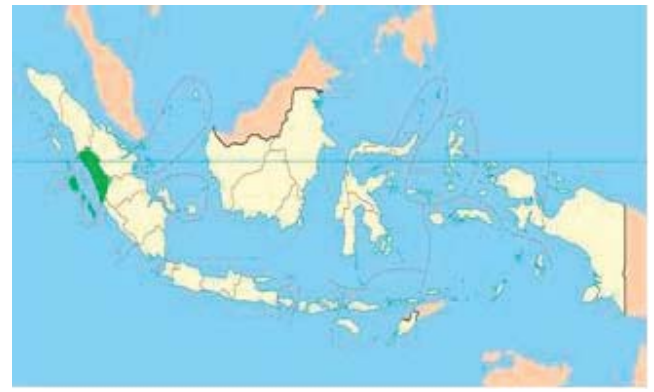

Fig.1. Location of West Sumatera in Indonesia

\subsection{Data and Methodology}

The definition of traditional Minangkabau building in this study is building house that is physically discrete, namely the main roof forms like buffalo horn, a square-shaped building and the main material used is wood, semi concrete or concrete. This study uses a quantitative approach to identify and collect field data through a survey on the whole of Minangkabau traditional buildings as the focus area of study. The total of the buildings had survey with amounts 1,122. The field studies involved the collection of data on the current physic conditions and function of this type of building by area. Observation physic conditions via observation of building material. It applied three categories namely: wood (almost whole material for construction is wood); semi concrete (material for construction is mixed wood and concrete); and concrete (whole of material for construction is concrete). The elements of material used for observation included pillars, floors and walls.

\section{Results and discussion}

The results in Table 1 show that the majority of the characteristics of Minangkabau traditional building materials still maintain traditional architecture using natural materials like wood. Nearly $28 \%$ of building materials are replaced by concrete. Buildings already renovated in concrete form replaced natural material though still maintain the characteristics and shape of the roof

Tabel 1. Characteristics of traditional Minangkabau building in urban and rural area

\begin{tabular}{|c|c|c|c|c|c|c|c|c|c|c|c|}
\hline \multirow{3}{*}{ Area } & \multirow{3}{*}{$\begin{array}{c}\text { Minangkabau } \\
\text { traditional } \\
\text { building }\end{array}$} & \multicolumn{4}{|c|}{ Material } & \multicolumn{6}{|c|}{ Function } \\
\hline & & \multicolumn{2}{|c|}{ Traditional } & \multicolumn{2}{|c|}{$\begin{array}{l}\text { Concrete and } \\
\text { semi concrete }\end{array}$} & \multicolumn{2}{|c|}{$\begin{array}{l}\text { The building } \\
\text { damaged }\end{array}$} & \multicolumn{2}{|c|}{ Not occupied } & \multicolumn{2}{|c|}{ As residence } \\
\hline & & $\mathrm{N}$ & $\%$ & $\mathrm{~N}$ & $\%$ & $\mathrm{~N}$ & $\%$ & $\mathrm{~N}$ & $\%$ & $\mathrm{~N}$ & $\%$ \\
\hline Urban & 511 & 372 & 72.80 & 139 & 27.20 & 99 & 19.37 & 23 & 4.50 & 389 & 76.13 \\
\hline Rural & 611 & 530 & 86.74 & 171 & 27.99 & 98 & 16.04 & 81 & 13.26 & 432 & 70.70 \\
\hline Total & 1,122 & 902 & 80.39 & 220 & 19.61 & 197 & 17.56 & 104 & 9.27 & 821 & 73.17 \\
\hline
\end{tabular}

Its function as a custom home and place for daily activities is still maintained up to $73.17 \%$. However, nearly $18 \%$ of house buildings are not occupied because of damages. Demographic changes in the family structure also affect the existence of traditional houses. The Minangkabau traditional house as a residence is only occupied by family members 
(women only) to do their daily activities. Thus, in a house more than one nuclear family will stay. In order to increase social and economic status in Minangkabau society a nuclear family will build their own house as part of the basic needs whilst improve comfort. Usually family members prefer to build a house around the traditional house building. This sometimes causes the traditional house building to become idle. Beside that, Table 1 shows that there is effect of cultural migration among Minangkabau ethnics with their traditional building. Nearly $14 \%$ of the building in rural areas is unoccupied because their owners stay in other areas. It shows that the special culture of Minangkabau "merantau' or migrate have influence on the existence of Minangkabau traditional building (Mochtar Naim 1972; 1979; Ranti Irsa et al 2012; Noviarti et al 2013)).
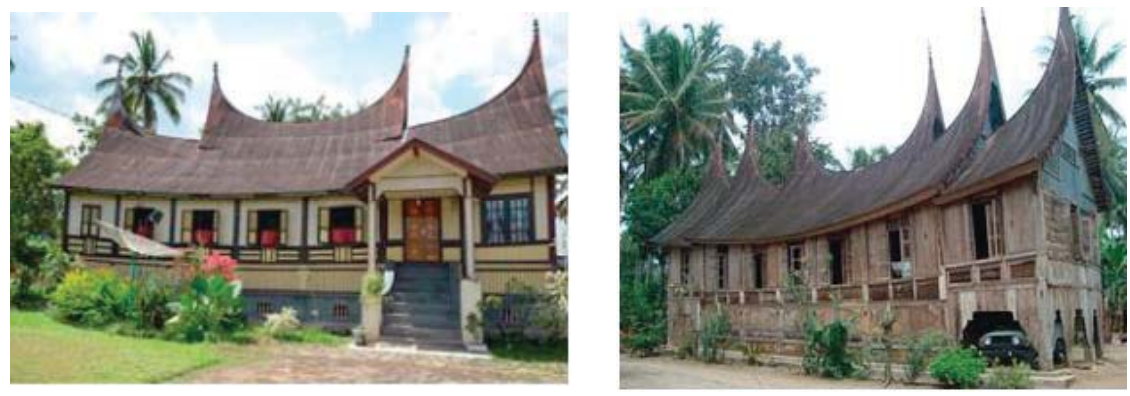

Fig. 2. The traditional Minangkabau buildings

Moreover, urbanization is believed to influence the society's economic structure in urban and rural areas. In that case, the socio-economic aspects mean the economic status of owners to repair the traditional building since high costs is required to do it. It is also a constrain factor causing traditional houses to be abandoned and damaged. However there are some adjustments done in society, such as develop a new building on the left side of the traditional building. Other adjustments for damaged building is to do renovation, natural material is replaced with concrete building material, while still maintaining the architectural form of the roof that reflects the characteristics of traditional building Minangkabau. In this case people assume that the cost of construction and maintenance of buildings with concrete material is cheaper than traditional material of wood.

Based on urban function, the building offers space for trade and services activity. Review of the urban system, shows that the urban development is based on development of roads and other infrastructure. If urbanisation process is associated with sustainability of Minangkabau traditional building, especially in the city centre there is impact of land use pressure for economic activity. In the city centre traditional building is not found along the main road, because the main street area is used for office buildings and economic facilities such as shops. In other parts of the city centre traditional building is still found in the main street. However its existence got pressure with economic activity, so the layout of traditional building changed. In that case, to improve their quality of life, the people modify the land use of the area for the needs of their lives (Jamaluddin Md. Jahi 1988).

\section{Conclusion}

Sustainability of Minangkabau traditional building is part of the habitat characteristics of a community. Urbanization too had an impact on sustainability of Minangkabau traditional building in Payakumbuh especially in the centre of urban areas. The physical sustainability of Minangkabau traditional building at urban area is maintained in terms of architecture and material. The implications of this study are important for urban planning policy. It is suggested that local governments need to make efforts for conservation of cultural heritage area of the city through the creation of local laws and regulations on the protection of cultural property, as these assets are valuable for culture and history. Traditional building conservation requires immediate action for the preservation as part of the habitat of the community sustainability.

\section{Acknowlegement}

This study was conducted by using the research funding of Hibah Bersaing. It is funded by Directorate General of Higher Education Indonesia (DIKTI) - Ministry of National Education, Ref. No. DIPA 023.04.2532476/2013 (Dipa Kopertis Wil X). 
The authors are thankful to Government of West Sumatera, for providing data and information. Our sincere gratitude to all the respondents that participate in the study for their kind co-operation and responses.

\section{References}

Adhisakti, Laretna T. (1991). Conservation Planning and Urban design of Historical Settlement, Penang Malaysia. 11 -16 Sept.

Al Busyra Fuadi. (2006). Transformasi Ruang Dalam Pada Rumah Gadang, Studi Kasus: Nagari Koto Baru, Kecamatan Sungai Pagu Kabupaten Solok Selatan. International Conference on Construction Industry (ICCI). Padang: Universitas Bung Hata, 21-24 Juni 2006.

Boestami. (1979). Rumah Gadang. Padang: Kanwil P \& K Propinsi Sumatera Barat.

Dobbin, C. (1983). Islamic Revivalism in a Changing Peasant Economy: Central Sumatera, 1784-1847. London: Curzon Press.

Carmona,M, (2003), Public Places Urban Space, The Dimention of Urban Design, Architectural Press, Oxford.

Elfida Agus. (2006). Kajian topologi, morfologi, dan tipologi pada rumah gadang minangkabau. Internasional Conference on Construction Industry (ICCI). Padang: Universitas Bung Hata, 21-24 Juni 2006.

Graves, E.( 1981). The Minangkabau Response to Dutch Colonial Rule Nineteenth Century. Itacha, New York: Cornell Southeast Asia Program Publication.

Jamaluddin Md. Jahi. (1988). Pengantar Geografi Fizikal. Kuala Lumpur: Tropikal Press Sdn. Bhd.

Kementerian Negara Lingkungan Hidup Republik Indonesia. (2008). Kota Ekologis: Panduan untuk Mewujudkan Kota, Komunitas dan Bangunan Ramah Lingkungan. Jakarta: Kementerian Negara Lingkungan Hidup Republik Indonesia.

Navis, (1984), Alam Takambang Jadi Guru. Jakarta: Grafiti Pers.

Mochtar Naim. (1972). Merantau dan pengaruhnya terhadap pembangunan daerah di Sumatera Barat. Padang: CSM.

Mochtar Naim. 1979. Merantau: pola migrasi suku Minangkabau. Yogyakarta: Gajah Mada University Press.

Noviarti, Jamilus \& Nelmawarni. (2009). Kelestarian Rumah Adat Tradisional Minangkabau di Sumatera Barat: isu dan reality. Proceeding Seminar Malaysia Indonesia, Universiti Kebangsaan Malaysia dengan Universitas Andalas. Bukittinggi. 19 Desember 2009.

Noviarti, Ranti Irsa \& Astuti Masdar. (2013). Preserving Minangkabau traditional building in West Sumatra: integration information technology. Procedia Envoronmental Sciences 17: 749-756.

Ranti Irsa, Noviarti, \& Astuti Masdar. (2012). Impact of urbanisation on sustainability of minangkabau traditional building in West Sumatera, Indonesia. 3rd International Conference on Human Habitat and Environment. Bangi: Universiti Kebangsaan Malaysia; 18-19 June 2012.

Sudirman Is (2006). Aplication of space conception in the Minangkabau traditional house at residence development . Internasional Conference on Construction Industry (ICCI). Padang: Universiras Bung Hata, 21-24 Juni 2006.

Sudirman Is( 2007). Arsitektur Tradisional Minangkabau: nilai-nilai budaya dalam arsitektur rumah adat. Padang: Bung Hatta University Press. 